\title{
In vitro evaluation of free radical-scavenging potentials of ethanol extract of Combretum dolichopentalum leaves
}

\author{
Favour Ntite Ujowundu* \\ Department of Biochemistry, Federal University of Technology, Owerri, Imo State, Nigeria
}

\begin{abstract}
The free radical-scavenging activities of the ethanol extract of Combretum dolichopentalum leaves were determined in this study. The effect of the crude ethanol extract in comparison with a standard plant antioxidant -quercetin and butylated hydroxyl toluene (BHT) for in vitro scavenging potentials showed dose dependent scavenging potentials on nitric oxide, hydroxyl radical, hydrogen peroxide -induced lipid peroxidation and reducing power. The results obtained indicated that ethanol extract of $C$. dolichopentalum leaf possess the ability to ameliorate the aetiologic and progression of oxidative stress related disease, since most antioxidant drugs used in the treatment of oxidative stress related diseases have strong reducing powers.
\end{abstract}

\section{Introduction}

There is no doubt that reactive oxygen specie (ROS) are essential for life as a result of their role in various vital processes such as signal transduction and the ability of phagocytes to carry out their bactericidal activity. Although meticulously controlled process regulate the generation of ROS for essential functions, many cellular processes result in the generation of ROS which constitute oxidative stress, such as in the electron transfer chain. The cytochrome P450 monooxygenase system of hepatic endoplasmic reticulum (microsomes) also generate a substantial amount of ROS in the process of metabolizing diverse group of chemical compounds, that include most of the drugs that we administer as well as environmental substances. Furthermore, enzymes such as xanthine oxidase system can also generate ROS. The interaction of reactive oxygen species with cellular macromolecules, including DNA, proteins and lipids interferes with vital cellular functions, and proceeds to the aetiologic and progression of many other diseases [1-2] such as cancer. Small molecular weight antioxidants and antioxidant enzymes scavenge ROS and protect organisms from the damaging effects of oxidative stress in vivo. However tissue antioxidants interception and scavenging of ROS is not $100 \%$ efficient. Thus, the need to enhance the abilities of endogenous antioxidants by introducing antioxidants of plant origin is important. Combretum dolichopentalum makes up the type genus of the family combretaceae and it is commonly known as 'food for the small bird'. Combretum dolichopentalum is employed in treating disease conditions of the alimentary tract in lgbo ethnomedicine, which includes stomach ulcer, diarrhoea, and passage of bloody stool, dysentery and gastro-intestinal disorder in Imo State of Nigeria. Plant derived drugs used in traditional medicine are a strong alternative to orthodox drugs because they are cheap, efficacious and possess little side effects. According to WHO, about $80 \%$ of world population still depend on herbal remedies [3]. Thus the aim of this study was to determine the radical scavenging potentials of $C$. dolichopentalum leaves, since the reducing capacity of a compound can serve as a significant indicator of its potential antioxidant activities.

\section{Materials and methods}

\section{Plant sample}

Fresh leaves of $C$. dolichopentalum were harvested from a farm in Obinze in Owerri West Local Government Area of Imo state. The location had a GPS coordinates of N5 ${ }^{\circ} 23^{\prime} 411^{\prime}$ ' and E $6^{\circ} 57^{\prime} 14.0^{\prime}$ and an elevation of $60 \mathrm{~m}$. The plant was identified by two plant taxonomists: Mr. A. Ozioko of Bioresource Development and Conservation Program (BDCP), Research Centre, Nsukka, Enugu State and Dr. F.N. Mbagwu of the Department of Plant Science and Biotechnology, Imo State University, Owerri, Nigeria. The sample specimen was deposited with voucher IMSUH12 at Imo State University Herbarium. The fresh leaves were plucked from their stems, washed and allowed to dry at room temperature. The dried samples were pulverized (using electric blender) and stored in an airtight container kept in a desiccator for 3 days.

\section{Preparation of ethanol extract of plant}

Three hundred grams of the pulverized sample was soaked in 1.75 L of $80 \%$ ethanol and extracts obtained after 48 hours [4]. This was done in three separate jars and then pooled together. The sediment was removed by coarse filtration using a sieve followed by a Whatman No 1 filter paper. The extract was concentrated using a rotary evaporator under mild temperature and labelled ethanol extract of Combretum dolichopentalum (EECD).

Determination of nitric oxide scavenging ability: The method described by Marococci et al. [5] relied on a diazotization reaction originally described by Griess [6]. The Greiss reagent system is

Correspondence to: Ujowundu FN. Department of Biochemistry, Federal University of Technology, Owerri, Imo State, Nigeria, E-mail: fnujowundu@ yahoo.com

Key words: Antioxidants, Nitric oxide, Hydroxyl radical, H2O2-induced lipid peroxidation, Combretum dolichopentalum

Received: July 20, 2017; Accepted: August 17, 2017; Published: August 21, 2017 
based on the chemical reaction which uses sulphanilamide and $\mathrm{N}-1$ naphthylethylene diamine dihydrochloride (NED) under acidic conditions. To start, $4 \mathrm{ml}$ of the extract of increasing concentrations were added to different test tubes containing $1 \mathrm{ml}$ of sodium nitroprusside (SNP) solution $(25 \mathrm{mM})$; the tubes were incubated at $29^{\circ} \mathrm{C}$ for 2 hours. Then $2 \mathrm{ml}$ aliquot of the incubated solution was removed and diluted with $1.2 \mathrm{ml}$ Greiss reagent. The absorbance of the chromophore that formed during diazotization of the nitrite with sulphanilamide and subsequent coupling with naphthylethylene diamine dihydrochloride was immediately read at $550 \mathrm{~nm}$ and referred to the absorbance of standard solution of sodium nitrite salt treated in the same way with Greiss reagent.

Calculation: The amount of nitrite produced was determined from a standard dose-response curve $y=-0.4289 \mathrm{x}^{2}+1.1534 \mathrm{x}+0.0093$ (correlation coefficient $\mathrm{R}^{2}=0.9968$ ). X was calculated from the second order polynomial equation. Inhibition of nitrite formation by extract and the standard plant antioxidant (Quercetin) were calculated relative to the control.

$$
\% \text { Inhibition }=\frac{100-(\text { Test } \times 100)}{(\text { Control })}
$$

Determination of hydroxyl radical scavenging ability: The method described by Halliwell et al. [7] is based on studying free radical dependent-2-deoxyribose degradation to malondialdehyde using the Fenton oxidant reaction mixture of $\mathrm{Fe}^{3+} /$ ascorbic acid and $\mathrm{H}_{2} \mathrm{O}_{2}$.

Hydroxyl radical scavenging ability was measured by studying the competition between deoxyribose and the test compounds for hydroxyl radical generated from the $\mathrm{Fe}^{3+} /$ ascorbate/EDTA/ $\mathrm{H}_{2} \mathrm{O}_{2}$ system. The reaction mixture contained the extract $(0-2000 \mathrm{ug} / \mathrm{l})$, $\mathrm{FeCl}_{3}(0.1 \mathrm{mM})$, EDTA $(0.1 \mathrm{mM}), \mathrm{H}_{2} \mathrm{O}_{2}(1 \mathrm{mM})$ ascorbate $(0.1 \mathrm{mM})$, $\mathrm{KH}_{2} \mathrm{PO}_{4} \cdot \mathrm{KOH}$ buffer $(20 \mathrm{mM}, \mathrm{pH} 7.4)$ and deoxyribose $(2.8 \mathrm{mM})$ in a final volume of $1.0 \mathrm{ml}$. After incubation at $37^{\circ} \mathrm{C}$ for 1 hour, deoxyribose degradation was measured as TBARS by the method of Okhawa et al. [8] as modified by Liu et al. [9].

Determination of thiobarbituric acid reactive substances (TBARS): To the incubation mixture were added, $1.5 \mathrm{ml}$ of $20 \%$ acetic acid (pH 3.5), $1.5 \mathrm{ml}$ of $0.8 \%$ thiobarbituric acid (TBA), $0.2 \mathrm{ml}$ of $8.1 \%$ sodium dodecyle sulphate (SDS). The mixture was heated at $100^{\circ} \mathrm{C}$ for 1 hour and cooled. Then $2 \mathrm{ml}$ of TCA was added. The mixture was vortexed vigorously and centrifuged at $300 \mathrm{x}$ g for 10 minutes and the absorbance read at $532 \mathrm{~nm}$

Calculation: Concentration of the thiobarbituric acid reactive substances (TBARS) was determined using the molar extinction coefficient of malondialdehyde. Inhibition of deoxyribose degradation which is a measure of hydroxyl radical scavenging ability was calculated by

$$
\% \mathrm{OH} \text { Radical scavenging }=100-\frac{\mathrm{MDA}_{\text {test }}}{\mathrm{MDA}_{\text {control }}} \times 100
$$

\section{Determination of hydrogen peroxide induced lipid peroxidation of rabbit brain homogenate (neuroprotection).}

The ability of C. dolichopentalum extract to inhibit lipid peroxidation was evaluated by incubating rabbit brain homogenates treated with $\mathrm{H}_{2} \mathrm{O}_{2}$ at different concentrations of the extract. This method was outlined by Muralikhrisnan et al. [10]. $\mathrm{H}_{2} \mathrm{O}_{2}$ induces lipid peroxidation in rabbit brain homogenates. Lipid peroxides react with thiobarbituric acid to form a pink product, thiobarbituric acid reacting substances (TBARS), measurable colorimetrically at $532 \mathrm{~nm}$. The difference between the control and C. dolichopentalum extract treated sample is the measurement of decrease in TBARS formation.
Whole rabbit brain was homogenized in phosphate buffered saline $(10 \% \mathrm{w} / \mathrm{v})$. Two hundred microliter $(200 \mu \mathrm{l})$ of the rabbit brain homogenate, 0 to $800 \mathrm{~g} / \mathrm{ml}$ of $C$. dolichopentalum extract, $10 \mu \mathrm{l}$ of hydrogen peroxide was incubated for 1 hour. TBARS were measured according to the method described by Liu et al. [9]. Briefly, to the incubation mixture were added $0.75 \mathrm{ml}$ of $20 \%$ acetic acid $(\mathrm{pH} \mathrm{3.5)}$, $0.75 \mathrm{ml}$ of $1.0 \%$ thiobarbituric acid (TBA), and $0.2 \mathrm{ml}$ of SDS (8.1\%). The mixture was heated at $100^{\circ} \mathrm{C}$ for 1 hour. Thereafter $2 \mathrm{ml}$ of $10 \%$ TCA was added and centrifuged at $6000 \mathrm{rpm}$ for 5 minutes and optical density taken at $532 \mathrm{~nm}$.

$$
\text { Calculation \%Inhibition }=\frac{100-\text { Test } \times 100}{\text { Control }}
$$

Determination of reducing power

The method according to Oyaizu [11] was used. This method determines the $\mathrm{Fe}^{3+} / \mathrm{Fe}^{2+}$ transformation in the presence of the test compound. The reducing capacity of the extract may serve as a significant indicator of its potential antioxidant activity [12]. Different concentrations $(0-1000 \mu \mathrm{g} / \mathrm{ml})$ of the extract and standard (butylated hydroxyl toluene) in different test tubes were mixed thoroughly with $2.5 \mathrm{ml}$ of $0.2 \mathrm{mM}$ phosphate buffer at $\mathrm{pH} 6.6$ and $2.5 \mathrm{ml}$ of $1 \%$ $\mathrm{K}_{3} \mathrm{Fe}(\mathrm{CN})_{6}$. The mixture was incubated at $50^{\circ} \mathrm{C}$ for 20 minutes, $2.5 \mathrm{ml}$ of the upper layer of the solution was mixed with $2.5 \mathrm{ml}$ of distilled water and $0.5 \mathrm{ml}$ of $0.1 \% \mathrm{FeCl}_{3}$. The absorbance was read at $700 \mathrm{~nm}$ in a Spectronic 20 spectrophotometer.

Calculation: Reducing power was determined from the plot of optical density against concentration of extract. Reducing power $\left(\mathrm{RP} 0.5_{\mathrm{Au}}\right.$ ) was taken as the concentration of extractable to give 0.5 absorbance reading.

\section{Statistical analysis}

Data generated are presented as percentage composition in mean and standard deviation. The plant extract free radical inhibition data (mean values from triplicate determinations) were fitted into kinetic equation- logistic-dose-response model and sigmoid abcd model, using Levenberg-Marquardt algorithm (Table curve 2D SYSTAT USA) [13].

\section{Results}

Figure 1 shows the nitric oxide (NO) scavenging potentials of ethanol extract of $C$. dolichopentalum (EECD). The result showed EECD as a better $\mathrm{NO}^{-}$scavenger compared to the plant standard quercetin. The threshold inhibitory concentration/scavenging power of EECD $(\mathrm{g} / \mathrm{ml})$ are shown in Table 1

The result of reducing power potential of EECD is shown in Figure 2. It revealed that EECD dose dependently transformed $\mathrm{Fe}^{3+}$ to $\mathrm{Fe}^{2+}$ indicating strong reducing power (See Appendix file). The concentration of extract able to give 0.5 absorbance unit was found to be $39.11 \mu \mathrm{g} / \mathrm{ml}$ for EECD, whereas $\mathrm{BHT}_{\text {was }} \mathrm{RP}_{0.5}=29.95 \mu \mathrm{g} / \mathrm{ml}$. The threshold inhibitory concentration/scavenging power of EECD $(\mu \mathrm{g} /$ $\mathrm{ml}$ ) are shown in Table 2

Figure 3 shows lipid peroxidation inhibition by C. dolichopentalum in rabbit brain homogenate. Inhibition of lipid peroxidation in rabbit brain homogenate by EECD showed an inhibition concentration less than that of the plant standard quercetin. The threshold Inhibitory concentration/scavenging power of EECD $(\mu \mathrm{g} / \mathrm{ml})$ are shown in Table 1

Figure 4 shows the hydroxyl radical $(\mathrm{OH})$ Scavenging potentials of C. dolichopentalum leaves. Ethanol extract of C. dolichopentalum caused a dose dependent threshold inhibiton concentration with an 


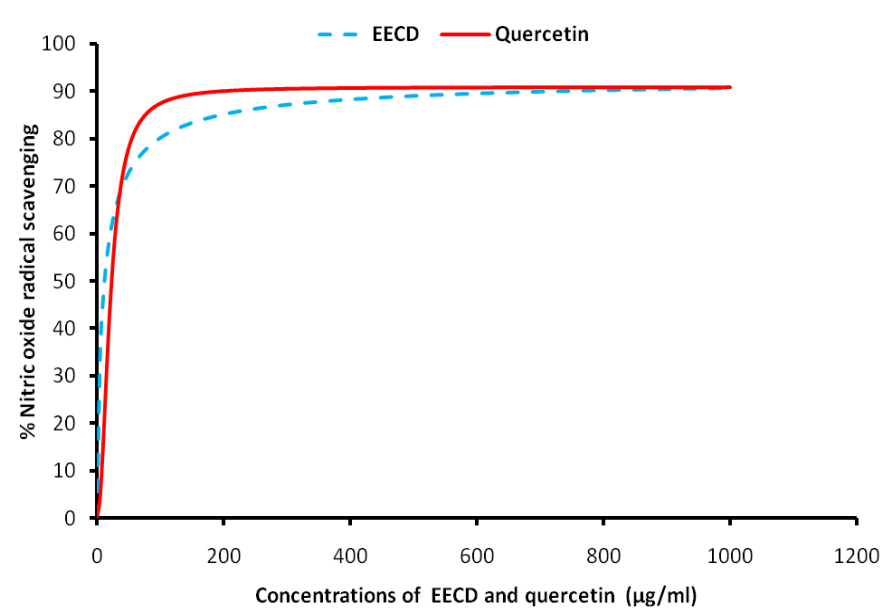

Figure 1. Nitric oxide (NO.) scavenging potentials of C. dolichopentalum.

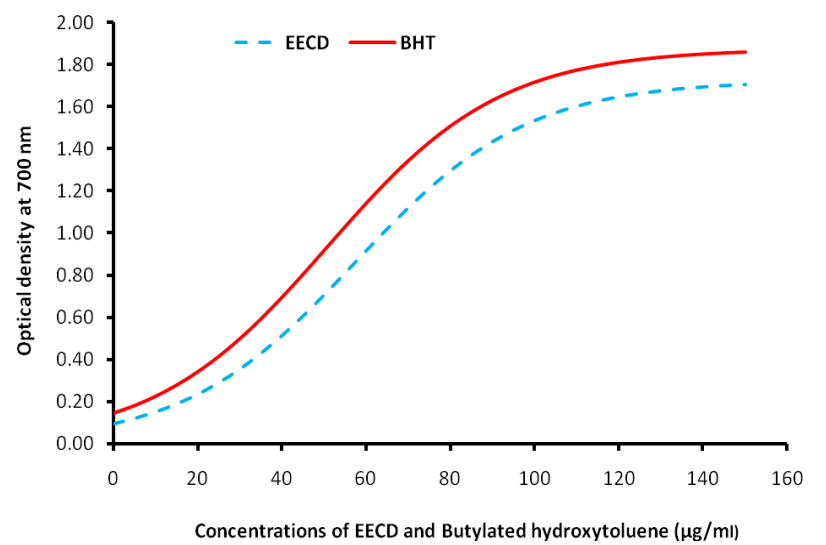

Figure 2. Reducing power of the ethanol extract of C. dolichopentalum.

Table 1. Threshold inhibitory concentration scavenging ability of Ethanol Extract of $C$. dolichopentalum on some free radicals reactive intermediates.

\begin{tabular}{|c|c|c|c|c|c|c|}
\hline & \multicolumn{6}{|c|}{ Threshold Inhibitory Concentration/Scavenging Power } \\
of EECD $(\mu \mathrm{g} / \mathrm{ml})$
\end{tabular}

Table 2. Reducing Power of Ethanol extract of Combretum dolichopentalum (EECD) on Iron (iii). Absorbance Unit concentration/reducing power of EECD $(\mu \mathrm{g} / \mathrm{ml})$.

\begin{tabular}{|c|c|}
\hline Reducing Power $(\mathrm{RP})$ & EECD $(\mu \mathrm{g} / \mathrm{ml})$ \\
\hline 0.1 & 0.61 \\
\hline 0.2 & 16 \\
\hline 0.3 & 25.63 \\
\hline 0.4 & 32.97 \\
\hline 1.5 & 39.11 \\
\hline
\end{tabular}

$\mathrm{IC}_{50}$ of $92.39 \mu \mathrm{g} / \mathrm{ml}$. The threshold Inhibitory concentration/scavenging power of EECD $(\mathrm{mg} / \mathrm{ml})$ are shown in Table 1

\section{Discussion}

One of the key players in the production of oxidoreductive stress is reactive oxygen species such as nitric oxides, hydroxyl radicals, as well as pro-oxidants like hydrogen peroxides. The results obtained in the in vitro nitric oxide scavenging potentials indicate that EECD is a better scavenger of nitric oxide (NO) radicals when compared to quercetin used as the standard compound (Figure 1) with a high correlation coefficient $\left(\mathrm{R}^{2}=0.9953\right)$. Ethanol extract of $C$. dolichopentalum nitric oxide scavenging ability followed a dose dependent manner, even at lower concentrations. NO radical is implicated in the inactivation and nitration of human superoxide dismutase. Nitrosative stress may lead to nitrosylation reactions that can alter the structure of proteins and so inhibit their normal function. Cells of the immune system produce both superoxide $\left(\mathrm{O}_{2}^{-}\right)$and nitric oxide (NO) during the respiratory burst triggered by inflammation processes [14]. Under this condition, nitric oxide and $\mathrm{O}_{2}^{-}$may react to produce significant amount of oxidatively active molecule- peroxynitrite anion (ONOO) which is a potent oxidising agent that can cause DNA fragmentation and lipid oxidation [15-17].

At $\mathrm{IC}_{5}, \mathrm{IC}_{10}, \mathrm{IC}_{20}$ and $\mathrm{IC}_{50}, \mathrm{EECD}$ scavenged NO better at the respective concentrations $(0.27 \mu \mathrm{g} / \mathrm{ml}, 0.069 \mu \mathrm{g} / \mathrm{ml}, 1.95 \mu \mathrm{g} / \mathrm{ml}$ and $12.04 \mu \mathrm{g} / \mathrm{ml}$ ), compared to the standard quercetin at the following concentrations $5.35 \mu \mathrm{g} / \mathrm{ml}, 7.69 \mu \mathrm{g} / \mathrm{ml}, 11.45 \mu \mathrm{g} / \mathrm{ml}$ and $23.21 \mu \mathrm{g} / \mathrm{ml}$ respectively. The observed NO scavenging effect of EECD may be due to the presence of such flavonoids as luteolin, kaempferol, quercetin, catechin, isorhamnetin [18].

The study of $\mathrm{Fe}^{3+} / \mathrm{Fe}^{2+}$ transformation in the presence of EECD leaves (Figure 2) proved that the EECD has a good reducing power (R.P $\left.0.5_{\mathrm{AU}}=29.95 \mu \mathrm{g} / \mathrm{ml}\right)$, compared to extracts of Chromoleana odorata ( $\mathrm{RP}$

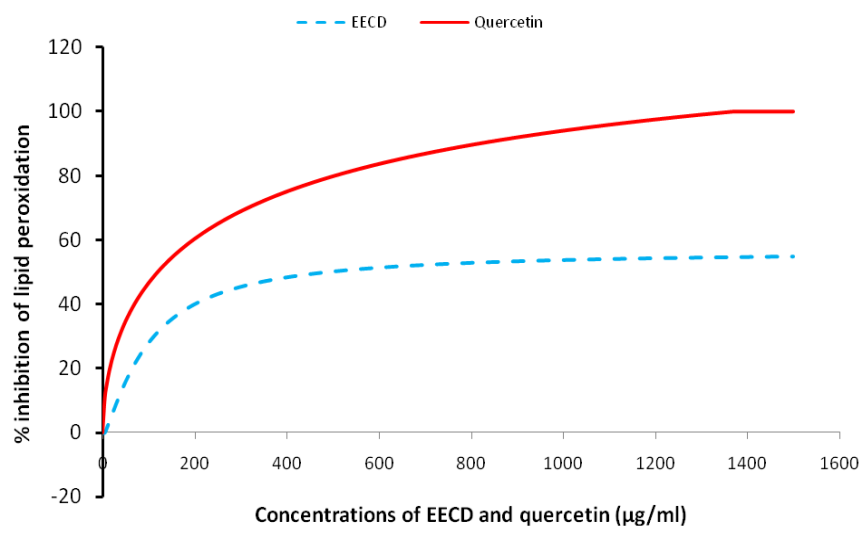

Figure 3. Lipid peroxidation inhibition by $C$. dolichopentalum in rabbit brain homogenate.

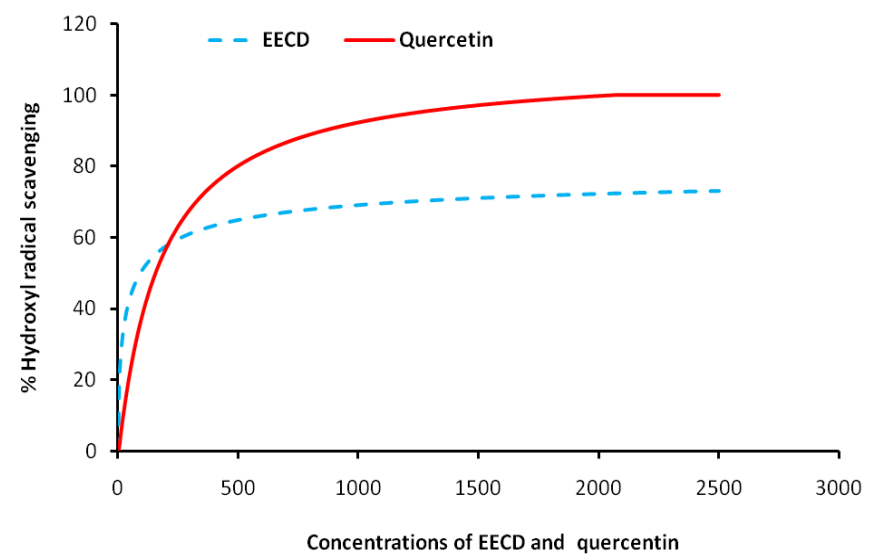

Figure 4. Hydroxyl radical (OH.) scavenging ability of C. dolichopentalum. 
$0.5_{\mathrm{AU}}=210.22 \mu \mathrm{g} / \mathrm{ml}$ ) [19]. Reducing power (RP) $0.5_{\mathrm{AU}}$ is the amount of extract to give 0.5 absorbance unit [20]. The reducing power of EECD was dose dependent with a high correlation coefficient $\left(\mathrm{R}^{2}=0.9932\right)$. The reducing capacity of a compound may serve as a significant indicator of its potential antioxidant activity [12]. Most antioxidant drugs used in the treatment of oxidative stress related diseases have strong reducing powers [21] and C. dolichopentalum leaf extract has shown appreciable content of antioxidant phytochemical [22]. Preventing lipid peroxidation to the brain is similar to protecting brain neurons (neuroprotection) [23,10]. Transmembrane transporters (such as P-glycoprotein) are important components of the blood-brain-barriers or blood testis-barrier [24]. Loss of function of the barriers can cause xenobiotics to cross the 'checkpoint' and induce undesired toxic effects in these otherwise well-shielded organs [25-27]. Quercetin used as the standard phytochemical, inhibited lipid peroxidation in rabbit brain homogenate better than EECD leaves (Figure 3). Nevertheless, EECD prevented peroxidation in rabbit brain homogenate at $64.70 \mu \mathrm{g} / \mathrm{ml}$ $\left(\mathrm{IC}_{50}\right)$. The brain is particularly vulnerable to oxidative damage because of its high oxygen utilization, high content of oxidizable polyunsaturated fatty acids and the presence of redox-active metals $(\mathrm{Cu}, \mathrm{Fe})$ [28-30]. Polyphenols cross the blood-brain barrier and can exert its antioxidant and iron chelating properties in the brain [23]. Polyphenols found in C. dolichopentalum includes kaempferol, quercetin, anthocyanidins etc [18]. A study by Moreira et al. [31] showed that oxidative stress plays an important role in the neurodegeneration and progression of Alzheimer's disease. Therefore EECD may play a role in the treatment and management of neurodegenerative diseases.

Hydroxyl radical $\left(\mathrm{OH}^{-}\right)$scavenging effects of $C$. dolichopentalum extract were studied in vitro. EECD significantly $(\mathrm{P}<0.05)$ inhibited $\mathrm{Fe}^{3+}$ /ascorbate/EDTA/ $\mathrm{H}_{2} \mathrm{O}_{2}$ system-induced deoxyribose sugar oxidation. At $92.39 \mu \mathrm{g} / \mathrm{ml}$ of EECD, the extract scavenged $50 \%\left(\mathrm{IC}_{50}\right)$ of $\mathrm{OH}^{-}$radicals generated. This value compared better than the standard plant derived phenolic antioxidant quercetin (Figure 4). Hydroxyl radical is formed by Fenton and Haber Weiss reaction and decomposition of peroxynitrite. Hydroxyl radical has a high positive activity, making it a very dangerous radical with a short in vivo half life of approximately $10^{-9}$ seconds [32]. Hydroxyl radical is one of the most damaging radicals in the body with the ability to attack and destroy DNA, proteins and lipids [33]. The $\mathrm{OH}^{-}$scavenging capacity of the extracts of $C$. dolichopentalum was high enough to consider it as a potential antioxidant compound. The inhibition of deoxyribose degradation by EECD was dose dependent with high correlation coefficient $\left(\mathrm{R}^{2}=0.9922\right)$. The major functions of antioxidants are to provide scavengers for ROS and reactive nitrogen species (RNS), to keep the cellular thiol redox status in the reduced form, to prevent or repair the oxidation of lipids, to sequester redox-active metals and to prevent Fenton type reactions [24]. This study has presented evidence to show that $C$. dolichopentalum possess high reducing power and can thus scavenge ROS as well as RNS.

\section{Competing interests}

I declare no competing interest.

\section{Acknowledgments}

I acknowledge Dr C.O Ujowundu, Prof A.I Ukoha, Dr R.N Nwaoguikpe, Prof A.O Ojiako and Dr. C.S. Alisi for their technical assistance and advice.

\section{References}

1. Van Gaal LF, Mertens IL, De Block CE (2006) Mechanisms linking obesity with cardiovascular disease. Nature 444: 875-880. [Crossref]
2. Rattan SIS (2006) Theories of biological ageing: genes, proteins and free radical. Free Radic Res 40: 123-1238. [Crossref]

3. Dharmasiri MG, Jayokody JRAC, Galhena G, Liyanage SSP, Ratnasooriya WD (2003) Anti-inflammatory and analgesic activities of natural fresh leaves of Vitex neyundo. $J$ Ethnopharmacol 7: 199-206. [Crossref]

4. Handa SS, Khanuja SPS, Longo G, Rakesh DD (2008) Extraction technologies for medicinal and aromatic plants. International centre for science and high technology. International Centre For Science And High Technology [Crossref]

5. Marococci I, Marguire JJ, Droy-lefaiz MT, Packer L (1994) The Nitric oxide scavenging properties Ginkgo biloba extract. Bioch and Biophys Res Com 201: 748755. [Crossref]

6. Griess, JP (1879) Bemerkungen zu der Abhandlung der HH. Weselsky und Benedikt, Ueber einige Azoverbindungen”. Ber Dtsch Chem Ges 12: 426-428. [Crossref]

7. Halliwell B, Gutteridge JMC, Aruoma OI (1987) The deoxyribose method: a simple "test tube" assay for determination of rate constants for reactions of hydroxyl radicals. Anal Biochem 165: 215-219. [Crossref]

8. Okhawa H, Oishi N, Yagi K (1979) Assay for lipid peroxides in animal tissue by thiobarbituric acid reaction. Analytical Biochemistry 95: 351-358. [Crossref]

9. Liu J, Edamatsu R, Kabuto H, Mori A (1990) Antioxidant action of guiligji in the brain of rats with $\mathrm{Fecl}_{3}$-induced rat epilepsy. Free Radical Biology and Medicine 9: 451-454. [Crossref]

10. Muralikhrisnan D, Binu T, Bala VM (2008) Antiparkinson drug - Mucuna puriens shows antioxidant and metal chelating activity. Phytotherapy Research 22: 6-11. [Crossref]

11. Oyaizu M (1986) Studies on products of browning reaction antioxidative activities of products of browning reaction from glucoseamine. Japanese Journal of Nutrition 44: 307-315. [Crossref]

12. Hsu B, Coupar IM, Ng K (2006) Antioxidant activity of hot water extract from the fruit of the Doum Palm, Hyphaene thebaica. Food Chemistry 98: 317-328. [Crossref]

13. Marquardt DW (1964) An algorithm for least squares estimation of non-linear parameters. Journal of the Society for Industrial and Applied Mathematics 2: 431-441. [Crossref]

14. Speakman JR, Selman C (2011) The free radical damage theory: Accumulating evidence against a simple link of oxidative stress to ageing and lifespan. BioEssays 33: 255-259. [Crossref]

15. Carr A, McCall MR, Frei B (2000) Oxidation of LDL by myeloperoxidase and reactive nitrogen species-reaction pathways and antioxidant protection. Arteriosclerosis Thrombosis Vascular Biology 20: 1716- 1723. [Crossref]

16. Klatt $\mathrm{P}$, Lamas $\mathrm{S}$ (2000) Regulation of protein function by $S$ glutathiolation in response to oxidative and nitrosative stress. European Journal of Biochemistry 267: 4928-4944. [Crossref]

17. Ridnour LA, Thomas DD, Manchardi D, Espey MG, Miranda KM, et al. (2004) The chemistry of nitrosative stress induced by nitric oxide and reactive and nitrogen oxide species. Putting perspectives on stressful biological situations. Biological Chemistry 385: 1-10. [Crossref]

18. Ujowundu FN, Ukoha AI, Ojiako AO, Nwaoguikpe RN (2015a) Gas chromatographic characterization of the flavonoids, alkaloids, saponins and tannins from $C$. dolichopentalum leaves. Journal of Chemical and Pharmaceutical Research 7: 10941103. [Crossref]

19. Alisi CS, Nwanyanwa CE, Akujobi CO, Ibegbulem CO (2008) Inhibition of dehydrogenase activity in pathogenic bacteria isolates by aqueous extracts of Musa paradisiacal (Van sapientum). Afr J Biotechnol 7: 1821-1825. [Crossref]

20. Alisi CS, Ojiako OA, Osuagwu CG, Onyeze GOC (2011) Free radical scavenging and in vitro antioxidant effects of ethanol extract of the medicinal herb Chromolaena Odorata Linn British J Anal Pharm Res 1: 141-155. [Crossref]

21. Dalton TP, Chen Y, Schneider SN, Nebert DW, Shertzer HG (2004) Genetically altered mice to evaluate glutathione homeostasis in health and disease. Free Radic Biol Med 37: 1511-1526. [Crossref]

22. Ujowundu FN, Ukoha AI, Ojiako AO, Nwaoguikpe RN (2015b) Isolation of bioactive phytochemicals in leaves of Combretum dolichopentalum and their hydrogen peroxide scavenging potentials. Pharm Anal Acta 6: 444. [Crossref]

23. Levites Y, Weinreb O, Maor G, Youdim YB, Mandel S (2001) Green tea polyphenol (-)-epigallocatechin-3-gallate prevents N-methyl-4-phenyl-1,2,3,6-tetrahydropyridine-induced dopaminergic neurodegeneration. Jounal of Neurochemistry 78: 1073-1082. [Crossref] 
24. Boelsterli UA (2007) Mechanistic Toxicology: The Molecular Basis of How Chemicals Disrupt Biological Targets. $2^{\text {nd }}$ Eds. CRC Press New York. pp: 54-61. [Crossref]

25. Matheny CJ, Lamb MW, Bronwer KLR, Pollack GM (2001) Pharmacokinetic and pharmacodynamic implications of p-glycoprotein modulation. Pharmacotherapy 21: 778-796. [Crossref]

26. Ayrton A, Morgan P (2001) Role of transport proteins in drug absorption, distribution and excretion. Xenobiotica 31: 469-497. [Crossref]

27. Arya V, Demarco VG, Issar M, Hochhaus G (2006) Contrary to adult, neonatal rats shows pronounced brain uptake of corticosteroids. Drug Metabolism and Disposition 34: 939-942. [Crossref]

28. Vega-Naredo I, Poeggeler B, Sierra-Sanchez V, Caballero B, Tomas-Zapico C, et al (2005) Melatonin neutralizes neurotoxicity induced by quinolinic acid in brain tissue culture. J Pineal Res 39: 266-275. [Crossref]
29. Khan A, Nazar H, Sabir SM, Irshad M, Awan SI, et al. (2014) Antioxidant Activity and Inhibitory Effect of Some Commonly Used Medicinal Plants Against Lipid PerOxidation in Mice Brain. Afr J Tradit Complement Altern Med 11: 83-90. [Crossref]

30. Bijita C, Khagen B (2016) Free Radical Mediated Diseases and their Prevention: An Ayurvedic Perspective. International Journal of Ayurveda and Pharma Research 4: 84-91. [Crossref]

31. Moreira S, Smith MA, Zhu X (2005) Oxidative damage and Alzheimers disease; are antioxidant therapies useful?. Drug News Prospect 18: 13-19. [Crossref]

32. Packer L, Weber SU, Rimbach G (2001) Molecular aspects of alpha-tocotrienol antioxidant action and cell signaling. Journal of Nutrition 131: 369S-373S. [Crossref]

33. Valko M, Morris H, Cronin MT (2005) Metals, toxicity and oxidative stress. Current Medical Chemistry 12: 1161-1208. [Crossref]

Copyright: $@ 2017$ Ujowundu FN. This is an open-access article distributed under the terms of the Creative Commons Attribution License, which permits unrestricted use, distribution, and reproduction in any medium, provided the original author and source are credited. 